\title{
Al-Yaqin in Critical Thinking: The Perception of Muslim Engineering Undergraduates in Malaysia
}

\author{
Mohd Nuri Al Amin Endut, Abdur-Rahman Mohamed Amin, Zulqarnain Abu Bakar, and Raja Ahmad \\ Iskandar Raja Yaacob
}

\begin{abstract}
The element of certainty or al-yaqin in the context of Islamic critical thinking deals with the Islamic epistemology, which normally relates to the certainty of knowledge. This element is deemed as the highest criterion of an Islamic epistemological state of knowledge that is engaged in the critical thinking process as well as its aimed result. Thus, the objective of this study was to analyze the perception of Muslim engineering students in Malaysian higher education institutions towards the concept of al-yaqin as an essential element of Islamic critical thinking. The study employed a survey-based descriptive research and the data were analyzed using a descriptive analysis. A total of 557 Muslim engineering undergraduates from six Malaysian universities participated in this study. The findings revealed that Muslim engineering undergraduates in the Malaysian higher learning institutions have rather good comprehension and consciousness of the element of certainty or al-yaqin. It also revealed that the students' perception on the theoretical context is better than their perception in the methodological context of al-yaqin.
\end{abstract}

Index Terms-Certainty, engineering education, epistemology, Islamic critical thinking.

\section{INTRODUCTION}

In this era of globalization, engineering students need to find intersections between spirituality and higher education to recapture the sense of values and purpose that brought them to their various roles and responsibilities in creating a future sustainable society [1]. The role of spirituality is potentially a very powerful avenue in personal and professional development through which the students construct a true meaning or vision of knowledge.

The Qur'anic expression of spirituality often articulates the structure of human cognitive consciousness together with other forms of thinking faculties of al- 'aql (intellect-reason), al-qalb (heart) and al-nafs (soul). These faculties certainly mark the significance of Islamic epistemological elements in which Muslim engineers are obliged to deal with different classification of senses and knowledge as well as different ways in deriving new information from them which lead to various levels of theory construction [2].

The role of spirituality is potentially a very powerful avenue in personal and professional development through which the students construct a true meaning of knowledge.

Manuscript received June 25, 2013; revised September 19, 2013. This work was supported in part by University Tekonologi PETRONAS's Short Term Internal Research Fund (STIRF) granted in 2012.

The authors are with the Universiti Teknologi PETRONAS, Bandar Seri Iskandar, 31750 Tronoh, Perak, Malaysia (e-mail: nuriend@petronas.com.my, urrahman_amin@petronas.com.my, zulqab@petronas.com.my, iskandar_yaacob@petronas.com.my).
Modern tertiary education, at least to some extent, has started to realize the importance of spirituality in higher education but awkwardly refuses to associate it within the context of religious faith and tradition. Thus spirituality is broadly defined as the internal process of seeking personal authenticity, genuineness, and wholeness that transcends one's locus of centricity, and develops a greater sense of connectedness to self and others through relationships and community [3].

\section{AL-YAQIN IN CRITICAL THINKING: ITS RELATION TO ENGINEERING EDUCATION}

The element of al-yaqin principally deals with the Islamic epistemology, which normally relates to the intellectual discourse on the sources, nature and method of knowledge. The term al-yaqin or certainty literally means knowledge (al-ilm), the removal of doubt (izahat al-shakk) or the affirmation of a state (tahqiq al-amr). Terminologically, al-Jurjani defines al-yaqin as 'a firm belief (I'tiqad) of a state of a matter with similar belief that it is unacceptable to have other than that state which is in accordance to the fact and impossible to be dissolved' [4]. While al-Fayyumi defines al-yaqin as 'knowledge generated from reflection and evidential derivation' [5].

Basically, this definition and concept of certainty or al-yaqin can be concisely conceived from two interrelated contexts; methodological and theoretical. The methodological context of al-yaqin embraces the procedural aspect of attaining certainty by realizing its opposite values and upholding its logical propositions as represented in one part of the above definitions. Whereas the theoretical context of certainty, on the other hand, signifies the assertions of those particular natures and elements that constitute al-yaqin state as manifested from the other part of the abovementioned definitions. These two contexts of al-yaqin, in spite of their differences, hold a strong relation between them in complementing each other and signify a strong element with regard to Islamic critical thinking.

The significance of al-yaqin element in connection with Islamic critical thinking is closely related to these two contexts of certainty. The methodological context that focuses on the practical and logical aspect of al-yaqin would naturally deal with the analytical process of knowledge verification and evaluation which is known to be an essential aspect of critical thinking. Typically this context explores the epistemological discourse on the sources and method of knowledge in examining its strength and validity. Moreover this methodological context, as being a process, is also part of the logical premises for the theoretical context of certainty 
that deliberates on the comprehension of the elements and state of al-yaqin. As such the theoretical context of certainty actually functions as the aimed objective of Islamic critical thinking. This context epistemologically relates to the nature of knowledge in which it ultimately confirms and upholds the definite logical affirmation of truth and spiritual tranquility of soul [6].

Unlike the Islamic epistemology of certainty, which engrosses knowledge with the belief in spiritual realm and the ultimate truth, the Western discourse on the concept tend to concentrate more on the psychological aspect of epistemological development and beliefs. Thus, instead of looking for the various natures, classifications and sources of knowledge in defining the belief, the western liberal epistemological study in education shows more interest in generally exploring the manner of how individuals come to know, the theories and beliefs they hold about knowing and how epistemological beliefs affect cognitive processes of thinking and reasoning [7]. From this perspective, the epistemological element of certainty in engineering education is discussed within the dimension of the absolute of knowledge; whether the knowledge is fixed as a set of stone or continuously evolving as fluid relativism which makes no distinctions between evidence-based reasoning and mere opinion [8].

Thus, the Western discussion on the concept of certainty is obviously different from the Qur'anic epistemological approach that stresses more on the conceptual and methodological context of knowledge in illustrating the cognitive proof structuring process as to attain the yaqin or certain state of faith.

Engineering is the kind of knowledge that would bring Muslims closer to Allah as stated in the concept of tawhid. It is the area where Muslims scrutinize the beauty and benefits of natural resources as the signs of Allah Supremacy. Thus, Muslim engineers must be certain of this knowledge for it basically acts as fundamental premises in the effort of reaching the certain state of faith.

On the other hand, it is also vital for today's engineering education to equip students with the ability to understand certainty and to handle ambiguity so that these potential engineers will be able to cope with tomorrow's complex engineering challenges [9]. In his context, not only Islamic critical thinking provides inclusive theories of knowledge and cognition, but it also decisively defines the state of certainty. The element of certainty should not be examined merely from one's perspective on the absolute of knowledge as it does not really reflect one's level of certainty. Certainty is not simply a matter of how and what one knows as discussed by Al-Farabi [10] in his conditions of certainty. It also requires a firm self-awareness state of "knowing that one knows" as it significantly help engineers to be thoughtful, certain and determined in justifying any technological decisions. Moreover this Islamic concept of certainty would definitely boost up Muslim engineers self-confidence as well as firm up their belief and character in becoming well-rounded and respected engineers.

The element of al-yaqin is essential to the Muslim engineers due to the affirmation of its epistemological standards and nature on the two edges of critical thinking context; from the data examination process to the conclusion of a belief. Moreover the concept of al-yaqin also serves to differentiate between factual and vague opinions, and to verify the sources status and reliability in constructing a certain inference of thought. As such the element of al-yaqin depicts a distinct and appropriate perspective of critical thinking that significantly distinguish Islamic critical thinking from the current or modern critical thinking taught in engineering education.

To date, it seems fairly difficult to come across a comprehensive research that has been conducted in relation to the Islamic view of critical thinking with a particular interest in the perception of Muslim undergraduates in Malaysian higher learning institutions. One of the studies of this context has been carried out in 2012 to analyze the perception of Muslim engineering students towards Islamic critical thinking at Universiti Teknologi PETRONAS [11]. It involves 100 undergraduate Muslim engineering students and consequently found out that the engineering students have positive perceptions towards Islamic critical thinking even though they have never learnt about Islamic critical thinking as a standalone subject. As an extension to that, a further study on the perception of Muslim engineering undergraduates towards the element of $a l$ - $a d l$ in Islamic critical thinking has been conducted in six Malaysian higher learning institutions. This study has shown a reasonably laudable comprehension in relating the religious stimulation and values with the engineering effort but reflected the lacking aspect of the perception from their deficient understanding of rational justice in Islam as the means to grasp the ultimate truth [12]. Nevertheless, the comprehension of Malaysian engineering undergraduates with regards to the element of al-yaqin in critical thinking has yet to be explored. Thus, the objective of this study is to analyze the perception of Muslim engineering undergraduates in Malaysian higher learning institutions towards the element of al-yaqin as one of the important elements in Islamic critical thinking.

\section{Methodology}

The study employed a qualitative approach where the survey data collection was conducted during lecture sessions at the campuses of the participating universities. Cluster sampling method was employed involving 557 Muslim engineering students from four public universities namely Universiti Teknologi Malaysia (UTM), International Islamic University Malaysia (IIUM), Universiti Sains Malaysia (USM) and University of Malaya (UM) and two private universities; University Teknologi PETRONAS (UTP) and Universiti Tenaga Nasional (UNITEN). The sample size of 557 respondents is considered more than sufficient for a $95 \%$ confidence level and a confidence interval of 5 .

The six universities were selected because the curriculums adopted at these universities are mostly stressed on the importance of critical thinking in their program objectives and faculty objectives. Moreover, they are among the Malaysian top-ranking universities and are known for their reputable engineering and technology programs.

To administer the survey, a self-developed research 
questionnaire was constructed comprises two sections; the first section (Section A) covers the respondent's demographic data and the second section (Section B) consist of 19 statement items, designed to gauge the undergraduates' perception of al-yaqin through its five core constitutional components of Firm Belief (4 items), Peace of Mind (3 items), Doubt Exclusion (4 items), Affirmative Verification (4 items) and Uppermost Cognition (4 items). Section B of the questionnaire employed the selected-response items format that dictated the responses on five-point Likert scale ranging from 1 for "strongly disagree" to 5 for "strongly agree".

An expert panel of 10 individuals from the areas of Islamic thoughts and Engineering were engaged to seek for their viewpoints, validating the content of the instrument used in the study; 7 of them looked into the area of Islamic thoughts and Education, while the other 3 dealt with the content from the engineering perspective. This survey questionnaire was then administered for a pilot study involving 59 Muslim students to test its reliability. The reliability test of the survey instrument revealed a Cronbach's alpha of 0.7 , which is considered as valid and acceptable.

\section{RESUlts AND Discussions}

The Muslim engineering undergraduates profile consists of five items which include information on gender, engineering program, year of study and current cumulative grade point average (CGPA). From the 557 respondents, $27.3 \%$ of them were from Universiti Teknologi Malaysia (UTM), $19.6 \%$ from International Islamic University Malaysia (IIUM), $16.7 \%$ from Universiti Sains Malaysia (USM), 9.1\% from University of Malaya (UM), 16.2\% from Universiti Teknologi PETRONAS (UTP) and $11.1 \%$ from Universiti Tenaga Nasional (UNITEN).

TABLE I: DEMOGRAPHIC PROFILE OF THE RESPONDENTS

\begin{tabular}{|c|c|c|c|}
\hline $\begin{array}{l}\text { Demographic } \\
\text { Variable } \\
\end{array}$ & Category & $\begin{array}{c}\text { Frequency } \\
(\mathbf{N}=\mathbf{5 5 7})\end{array}$ & $\begin{array}{c}\text { Percentage } \\
(\%)\end{array}$ \\
\hline \multirow[t]{6}{*}{ University } & A - UTM & 152 & 27.3 \\
\hline & B - IIUM & 109 & 19.6 \\
\hline & C - USM & 93 & 16.7 \\
\hline & D - UM & 51 & 9.1 \\
\hline & E - UTP & 90 & 16.2 \\
\hline & F - UNITEN & 62 & 11.1 \\
\hline \multirow[t]{2}{*}{ Gender } & Male & 304 & 54.6 \\
\hline & Female & 253 & 45.4 \\
\hline \multirow[t]{4}{*}{ Year of Study } & $1^{\text {st }}$ Year & 21 & 3.8 \\
\hline & $2^{\text {nd }}$ Year & 151 & 27.7 \\
\hline & $3^{\text {rd }}$ Year & 122 & 22.3 \\
\hline & $4^{\text {th }}$ Year & 252 & 46.2 \\
\hline \multirow[t]{9}{*}{ Programme } & $\begin{array}{l}\text { Chemical } \\
\text { Engineering }\end{array}$ & 36 & 6.5 \\
\hline & $\begin{array}{l}\text { Mechanical } \\
\text { Engineering }\end{array}$ & 70 & 12.6 \\
\hline & Civil & 102 & 18.4 \\
\hline & Engineering & & \\
\hline & Petroleum & 41 & 7.4 \\
\hline & Engineering & & \\
\hline & Electrical & 183 & 33.0 \\
\hline & Engineering & & \\
\hline & Others & 122 & 22.0 \\
\hline \multirow[t]{5}{*}{ CGPA } & $3.50-4.00$ & 60 & 11.0 \\
\hline & $3.00-3.49$ & 223 & 40.9 \\
\hline & $2.50-2.99$ & 191 & 35.0 \\
\hline & $2.00-2.49$ & 68 & 12.5 \\
\hline & Below 2 & 3 & 0.6 \\
\hline
\end{tabular}

The analysis of respondents' profile (See Table I) exhibits that the gender representation was $54.6 \%$ male and $45.4 \%$ female that appeared to be fairly proportionate for this study. In terms of the year of study, the largest number came from the third and fourth year students that represented $68.5 \%$ of the respondents which would portray a better representation of the result as they have gained more exposure to the engineering concepts and profession. In terms of CGPA, majority $(75.9 \%)$ of the respondents were average achievers who score from 2.5 to 3.49 point. The high achievers of the respondents, on the other hand, have been represented by an acceptable portion of $11 \%$ of the respondents who score from 3.50 to 4.00 point. In general, the profiles of the respondents have shown an acceptable well-balanced result that could fairly represent the Muslim engineering undergraduates in Malaysian higher learning institutions.

The perception of al-yaqin can be gauged through the respondents' comprehension and consciousness of its five mentioned essential components. The perception of the respondents with regards to these components of al-yaqin is shown in Table II.

TABLE II: THE MEAN DISTRIBUTION OF THE COMPONENTS OF AL-YAQIN

\begin{tabular}{|c|c|c|c|}
\hline $\begin{array}{c}\text { Yaqin } \\
\text { Components }\end{array}$ & Mean & $\begin{array}{c}\text { Std. } \\
\text { Deviation }\end{array}$ & $\begin{array}{c}\text { Interpretatio } \\
\text { n }\end{array}$ \\
\hline Firm Belief & 3.36 & 0.54 & $\begin{array}{c}\text { Moderately } \\
\text { High }\end{array}$ \\
\hline Peace of Mind & 3.40 & 0.56 & $\begin{array}{c}\text { Moderately } \\
\text { High }\end{array}$ \\
\hline Doubt Exclusion & 3.27 & 0.56 & $\begin{array}{c}\text { Moderately } \\
\text { High }\end{array}$ \\
\hline $\begin{array}{l}\text { Affirmative } \\
\text { Verification }\end{array}$ & 3.57 & 0.43 & $\begin{array}{c}\text { Moderately } \\
\text { High }\end{array}$ \\
\hline $\begin{array}{l}\text { Uppermost } \\
\text { Cognition }\end{array}$ & 3.70 & 0.57 & $\begin{array}{c}\text { Moderately } \\
\text { High }\end{array}$ \\
\hline Overall Average & 3.48 & 0.35 & $\begin{array}{c}\text { Moderately } \\
\text { High }\end{array}$ \\
\hline
\end{tabular}

In general the table shows that the perception of Muslim engineering undergraduates on the element of al-yaqin is moderately high with the overall mean score of 3.48 ( $S D=$ 0.35). Only two of the five components exceed the mean score of 3.5; the component of Uppermost Cognition scored the highest mean of $3.70(S D=0.57)$ and the Affirmative Verification component attained the mean score of 3.57 (SD $=0.43$ ). The other three components namely Peace of Mind, Firm Belief and Doubt Exclusion have the mean score below 3.5 , specifically $3.40(S D=0.56), 3.36(S D=0.54)$ and 3.27 $(S D=0.56)$, respectively.

Table III deliberates more on the al-yaqin finding. The finding has notably shown that there is only one item that recorded high level of perception with a mean score above 4.00. The item is 'accept verified and reliable data' from the component of Affirmative Verification with the mean of 4.10 $(S D=0.75)$ with $83.1 \%$ of the respondents either strongly agreed or agreed with the item. However, there are few items that almost reach the mean score of high perception such as the items 'make decision based on convinced data', 'sure that engineering principle is true fact' and 'improve knowledge from doubt to certainty' which respectively scored the means of $3.92(S D=0.72), 3.88(S D=0.79)$ and $3.86(S D=0.77)$. Nevertheless these three items are still categorized as moderately high perception. 
TABLE III: The Distribution of Percentage AND MEAN of THE COMPONENTS OF AL-YAQIN

\begin{tabular}{|c|c|c|c|c|c|c|c|c|}
\hline al-Yaqin & Item Description & $\begin{array}{c}\text { SDA } \\
\%\end{array}$ & $\begin{array}{c}\text { DA } \\
\%\end{array}$ & $\begin{array}{l}\mathbf{N} \\
\%\end{array}$ & $\begin{array}{l}\mathbf{A} \\
\%\end{array}$ & $\begin{array}{c}\text { SA } \\
\%\end{array}$ & Mean & Interpretation \\
\hline \multirow{4}{*}{ 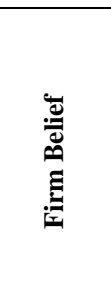 } & $\begin{array}{l}\text { Sure that engineering principle is } \\
\text { true fact }\end{array}$ & 0.9 & 2.7 & 24.4 & 51.2 & 20.6 & 3.88 & Moderately High \\
\hline & $\begin{array}{l}\text { No doubt on the basic principle of } \\
\text { engineering }\end{array}$ & 1.6 & 10.8 & 27.5 & 45.6 & 14.5 & 3.60 & Moderately High \\
\hline & $\begin{array}{l}\text { Cannot accept things against } \\
\text { engineering fundamental theory }\end{array}$ & 9.2 & 34.6 & 37.2 & 16 & 3.1 & 2.69 & Moderately Low \\
\hline & $\begin{array}{l}\text { Believe that current engineering } \\
\text { facts are indisputable }\end{array}$ & 3.9 & 13.5 & 40.8 & 34.5 & 7.4 & 3.28 & Moderately High \\
\hline \multirow{3}{*}{ 忒 } & Convinced by my own argument & 7 & 26 & 37.2 & 23.7 & 6.1 & 2.96 & Moderately Low \\
\hline & $\begin{array}{l}\text { Certain of my engineering } \\
\text { knowledge }\end{array}$ & 0.9 & 3.4 & 32 & 50.4 & 13.1 & 3.72 & Moderately High \\
\hline & $\begin{array}{l}\text { Firm engineering comprehension } \\
\text { bring tranquillity }\end{array}$ & 3.1 & 8.3 & 37.3 & 36.1 & 15.3 & 3.52 & Moderately High \\
\hline \multirow{3}{*}{ 总 } & $\begin{array}{l}\text { Not make decision based on } \\
\text { assumptions }\end{array}$ & 2.3 & 15.1 & 32.5 & 35.4 & 14.7 & 3.45 & Moderately High \\
\hline & Speculation is not an acceptable data & 2.5 & 19.7 & 45.1 & 26 & 6.3 & 3.14 & Moderately High \\
\hline & $\begin{array}{l}\text { Not hesitate to make critical } \\
\text { engineering decision }\end{array}$ & 2 & 16.9 & 43.1 & 32.5 & 5.6 & 3.23 & Moderately High \\
\hline \multirow{4}{*}{ 胥䒿 } & $\begin{array}{l}\text { Make decision based on convinced } \\
\text { data }\end{array}$ & 0.5 & 2.7 & 19.4 & 59.4 & 18 & 3.92 & Moderately High \\
\hline & Accept verified and reliable data & 0.9 & 1.3 & 14.7 & 53.7 & 29.4 & 4.10 & High \\
\hline & $\begin{array}{l}\text { Evaluate the strength and reliability } \\
\text { of data }\end{array}$ & 0.7 & 3.4 & 23.2 & 57.5 & 15.1 & 3.83 & Moderately High \\
\hline & $\begin{array}{l}\text { Decision and its supporting data } \\
\text { must equally convincing }\end{array}$ & 11.7 & 44.9 & 31.1 & 10.1 & 1.8 & 2.45 & Moderately Low \\
\hline \multirow{4}{*}{ ن } & $\begin{array}{l}\text { Conscious of the highest certainty } \\
\text { level }\end{array}$ & 1.3 & 6.3 & 33.4 & 46 & 13.1 & 3.63 & Moderately High \\
\hline & $\begin{array}{l}\text { Can differentiate doubt, assumed } \\
\text { and certain data }\end{array}$ & 1.6 & 7.2 & 38.6 & 43.3 & 9.3 & 3.52 & Moderately High \\
\hline & $\begin{array}{l}\text { Improve knowledge from doubt to } \\
\text { certainty }\end{array}$ & 1.3 & 2.5 & 22.4 & 56.7 & 17.1 & 3.86 & Moderately High \\
\hline & $\begin{array}{l}\text { Can distinguish vague and factual } \\
\text { opinion }\end{array}$ & 0.7 & 4.5 & 26.8 & 49.9 & 18.1 & 3.80 & Moderately High \\
\hline
\end{tabular}

There are fourteen items which scored moderately high perception of the al-yaqin elements with the mean score values ranging from 3.92 to 3.14 including the three highest score items mentioned above. This wide range of mean score values signified some sort of inconsistency and variations of responses towards the element. Interestingly, this well scattered or distributed mean score is clearly noticeable in the component of Affirmative Verification, for which both the highest and the lowest mean scores have been recorded. While three items rated as moderately low level of perception recorded mean score below 3.00. The items are 'decision and its supporting data must be equally convincing' under the Affirmative Verification component, 'cannot accept things against engineering fundamental theory' from the component of Firm Belief and 'convinced by my own argument' from the Peace of Mind component which recorded the lowest mean score of $2.45(S D=0.89), 2.69(S D=0.95)$ and 2.96 $(S D=1.01)$ respectively.

Generally, the overall result recorded in the study has shown that the respondents possess rather a fair and acceptable comprehension and awareness on the element of al-yaqin. In most cases, Muslim engineering undergraduates in Malaysian higher learning institutions are perceived to be able to distinguish certain facts and data. They also seem to be aware of the basis of the Islamic epistemological standard of certainty as compared to doubt and conjecture. This observable pattern of perception is relatively apparent from the higher mean score recorded in the Uppermost Cognition component and the other items related to the similar context. However, this satisfactory perception of the respondents appeared to be more related to some features of the theoretical context whereas the level of perception on the methodological context of al-yaqin seems to be relatively low. This concern is rather evident from the lowest mean score of the Doubt Exclusion component that deals mainly with the methodological contexts. Thus, the finding has indicated that the Muslim engineering undergraduates in Malaysian higher learning institutes seem to have a moderately good basic comprehension on the element of al-yaqin from its theoretical context, but possess a rather weak perception on the methodological context.

\section{IMPLICATIONS OF THE FINDING}

The study has basically presented the epistemological framework of the Islamic critical thinking. It has also explored the significance of that thinking within the engineering education and revealed the overall perception of Muslim engineering students towards that thinking. The findings of this study would definitely have some 
implications for the western concept of critical thinking and its dissemination among the Muslim engineering undergraduates.

The proposed conceptual definition of Islamic critical thinking has offered a unique and holistic perspective that distinguishes it from the existing critical thinking. More importantly, it has offered the Muslim undergraduates the concept of critical thinking that suits the Islamic vision and worldview that helps to strengthen the students' religious consciousness and comprehension as well as fortify them from the secular conception of critical thinking. The proposed concept of Islamic critical thinking from its contextual element of al-yaqin characterizes the thinking's distinctive nature from its epistemological context to make it more presentable to all Muslim undergraduates. Thus it opens a clear path for Muslim educationists to opt for this new framework of Islamic critical thinking instead of relying on a Western perspective of such thinking.

The overall finding of the study has brought to light some improper perception among Muslim engineering undergraduates of the insight and true meaning of engineering from the Islamic worldview. They only managed to relate the two areas at the surface. These students seemed to have failed to realize that engineering ventures are actually part of the broad and comprehensive aspect of Islamic teaching. This rather unfortunate circumstance calls for an effort and initiative to review the curriculum, particularly on the thinking and religious courses offered in Malaysian universities. These Muslim undergraduates need to be well conscious of the Islamic worldview and be able to integrate the religious values into their engineering knowledge and practices. They need to realize that they are actually performing their religious task and obligation by means of engineering. They have to deliberately deem engineering as the act of worship.

All of the abovementioned circumstances have implied significant concerns that require some changes and modifications in modeling the framework of Islamic critical thinking as well as reconstructing the thinking related courses in engineering education, to be initiated by Muslim educationist and Malaysian engineering faculties.

\section{CONCLUSION}

The As a conclusion, the Muslim engineering undergraduate students in Malaysian higher learning institutions possess a fair and acceptable comprehension towards the element of al-yaqin in Islamic critical thinking especially in evaluating the validity and reliability of the data in order to use it to make a decision. This study also shows that the students' perception on the theoretical context of al-yaqin is better than their perception in the methodological context. The students seemed to be aware on how to evaluate and verify data, but fell short to comprehend the nature of al-yaqin as one of the important element in Islamic critical thinking.

\section{REFERENCES}

[1] R. R. A. Razak, "Spiritual dimension in education: The role of institution of higher education," The International Journal of the
Humanities, Melbourne: Common Ground Publishing Pty Ltd, vol. 8, no. 11, pp. 46, 2011.

[2] O. Bakar, The History and Philosophy of Islamic Science, Islamic Texts Society, Cambridge, 1999, pp. 249.

[3] J. A. Lindholm and H. S. Astin, "Understanding the interior life of faculty: How important is spirituality?" Religion and Education, Iowa: University of Northern Iowa, vol. 33, no. 2, pp. 65, Spring 2006.

[4] I. Manzur and J. al-Din M. bin Mukrim, Lisan al-'arab, Dar Sadir, Beirut, 1990, vol. 13, pp. 457.

[5] See: Al-Jurjani, "Ali bin Muhammad bin Ali al-Husayni," al-Ta'rifat, Dar al-Kutub al-'Ilmiyyah, Beirut, 2000, $1^{\text {st }}$ ed., pp. 255. Also see: Murtada al-Zubaydi, Muhammad bin Muhammad, Taj al-'Arus Min Jawahir al-Qamus, vol. 9, pp. 370.

[6] M. Z. bin Ismail, "The sources of knowledge in al-Ghazali's thought," International Institute of Islamic Thought and Civilization (ISTAC), Kuala Lumpur, 2000, pp. 6.

[7] B. K. Hofer and P. R. Pintrich, "The development of epistemological theories: Beliefs about knowledge and knowing and their relation to learning," Review of Educational Research, Washington: American Educational Research Association, vol. 67, no. 1, pp. 88, 1997.

[8] B. A. King and M.-J. Susan, "Epistemological beliefs of engineering students," The Journal of Technology Studies, Ohio, vol. 35, no. 2, pp. 57, 2009. Also see: Marlene Schommer, "Effects of beliefs about the nature of knowledge on comprehension," Journal of Educational Psychology, the American Psychological Association, vol. 82, no. 3, pp. 498-499, 1990.

[9] J. Bordogna. (Spring 1997). Making connections: The role of engineers and engineering education. The Bridge. (A Publication of the National Academy of Engineering). National Academy of Engineering. [Online]. 27(1). Available: http://www.nae.edu/Publications/Bridge/EngineeringCulture.aspx.

[10] Al-Farabi and M. bin M. bin Tarkhan, "Sharait al-Yaqin," al-Mantiq inda al-Farabi, Majid Fakhri (ed.), Dar al-Mashriq, Beirut, 1987, pp. 98. Also see: Deborah L. Black, "knowledge ('ilm) and Certitude (yaqîn) in al-Fârâbî’s Epistemology," Arabic Sciences and Philosophy: a Historical Journal, Cambridge University Press, Cambridge, vol. 16, no. 1, pp. 4, 2006.

[11] M. A. A. Rahman, A. E. M. Nuri, R. M. A. Mahari, A. B. Zulqarnain, and A. I. R. Y. Raja, "Islamic critical thinking: The perception of muslim engineering students in Universiti Teknologi PETRONAS," in Proc. International Conference on Management, Social Sciences and Humanities 2012, Kuala Lumpur, Malaysia, 2012, pp. 163-166.

[12] M. N. A. A. Endut, W. S. W. Abdullah, and Z. A. Bakar, "The islamic element of AL-ADL in critical thinking: The perception of Muslim engineering undergraduates in Malaysia," in Proc. World Academy of Science, Engineering and Technology (WASET), Switzerland, 2012, pp. 759-764.

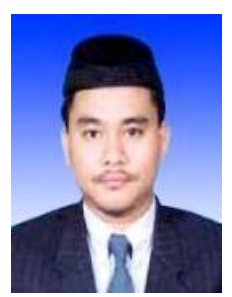

Mohd Nuri Al Amin Endut was born in Terengganu, Malaysia in 1969. He is currently a Senior Lecturer at the Department of Management and Humanities, Universiti Teknologi Petronas, Bandar Seri Iskandar, Perak, Malaysia. He obtained his $\mathrm{PhD}$ in Islamic Thought from University of Malaya, Malaysia early this year. He completed his Bachelor of Arts in Islamic and Arabic Studies from Al-Azhar University in Egypt and Master of Arts in Islamic Theology and $D a^{\prime}$ wah in AL al-Bayt Universiti in Jordan. His academic and research interests include Islamic Da'wah Movement in Malaysia, Islamic Critical Thinking, Islamic Science and Islamic Theology.

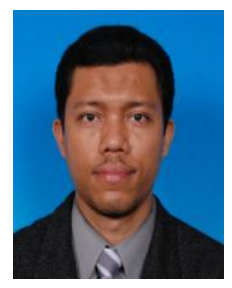

Abdur-Rahman Mohamed Amin was born in Terengganu, Malaysia in 1977. He graduated with a Bachelor of Arts (Hons) from International Islamic University Malaysia and a Master of Arts in Islamic Studies from University of Malaya in 2007. Currently he is a Lecturer at the Department of Management and Humanities, Universiti Teknologi PETRONAS, Bandar Seri Iskandar, Perak, Malaysia. His academic and research interests include the classical Jawi manuscript, biography of Muslim scholars in Southeast Asia and Malay intellectual history. 


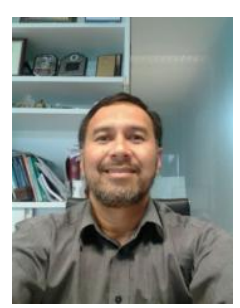

Zulqarnain Abu Bakar is a senior lecturer at the Department of Management and Humanities, Universiti Teknologi Petronas. He holds a Bachelor Degree in English Literature and a Master Degree in Applied Linguistics from George Mason University, Fairfax, Virginia U.S.A. He completed his $\mathrm{PhD}$ in Linguistics at Lancaster University, U.K. Having had more than 20 years of experience as an academician, his research interests include oral communication, phonetics and phonology, error feedback, error correction in pronunciation and language acquisition.

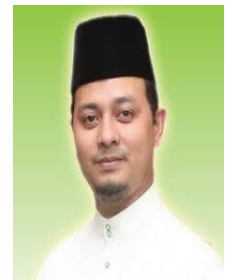

Raja Ahmad Iskandar Raja Yaacob was born in 1974 in Perak, Malaysia. He graduated from International Islamic University in 1998 in BHsc Political Science and obtained his MSc in Information Management from Universiti Teknologi Mara in 2000. He completed his $\mathrm{PhD}$ in Knowledge Management from the University of Manchester in 2011. He is actively doing his research in politics and information society. Currently he is a Senior Lecturer at the Department of Management and Humanities, Universiti Teknologi Petronas. 